\title{
The threat of myrtle rust to Māori taonga plant species in New Zealand
}

\author{
D.A.J. Teulon ${ }^{1,5}$, T.T. Alipia ${ }^{1,5}$, H.T. Ropata ${ }^{2,5}$, J.M. Green ${ }^{2}$, S.L.H. Viljanen- \\ Rollinson $^{1,5}$, M.G. Cromey ${ }^{1,5}$, K. Arthur ${ }^{2}$, R.M. MacDiarmid ${ }^{2,5}$, N.W. Waipara ${ }^{3}$ and \\ A.T. Marsh $^{4}$ \\ ${ }^{1}$ The New Zealand Institute for Plant E Food Research Limited, Private Bag 4704, \\ Christchurch 8140, New Zealand \\ ${ }^{2}$ The New Zealand Institute for Plant E Food Research Limited, Private Bag 92169, \\ Auckland, New Zealand \\ ${ }^{3}$ Auckland Council, Bledisloe House, Aotea Square, Private Bag 92300, Auckland \\ ${ }^{4}$ The New Zealand Institute for Plant E Food Research Limited, Private Bag 11600, \\ Palmerston North, New Zealand \\ ${ }^{5}$ Better Border Biosecurity (B3), New Zealand (http://b3nz.org) \\ Corresponding author:david.teulon@plantandfood.co.nz
}

\begin{abstract}
Myrtle rust, caused by the pathogen Puccinia psidii, is a disease of plants in the Myrtaceae that is currently not known to be present in New Zealand. Its origin is Central/ South America, but it has steadily spread around the world and is now found in Australia. All New Zealand Myrtaceae species, including indigenous species, are at risk from myrtle rust infection, but the extent of the impact on plant health is not known. While the potential economic and environmental impacts of myrtle rust establishment in New Zealand have been well documented, this paper explores potential socio-cultural consequences for Māori. All indigenous Myrtaceae species can be considered as taonga (or treasure) by Māori, who have and continue to use the properties of some species in many ways (both tangible and intangible). Preparedness and response plans for a myrtle rust incursion in New Zealand should consider the values that Māori derive from these plants.
\end{abstract}

Keywords myrtle rust, Puccinia psidii, Māori, taonga species, Myrtaceae.

\section{INTRODUCTION}

There is considerable concern about the likely arrival, establishment and impact of myrtle rust on introduced and indigenous plant species of the Myrtaceae in New Zealand (Clark 2011). Myrtle rust, caused by the pathogen Puccinia psidii in the Order Pucciniales, is a disease of many plants belonging to the Myrtaceae. Its origin is thought to be Central and South America (Glen et al. 2007), but it has been steadily moving around the world in recent years and is now found in New Zealand's close neighbours, Australia (including recently Tasmania) and New Caledonia (CABI 2014).

Clark (2011) provided a comprehensive review of the taxonomy, biology, host range and plant associations, geographic distribution, risk of entry, spread and establishment for $P$. psidii into New Zealand and its potential economic and environmental impact. In summary, she concluded that there is a high likelihood of arrival of entry to New Zealand and subsequent climate 
modelling identified that much of the North Island and a very small area in the north of the South Island are climatically suitable for $P$. psidii (Kriticos et al. 2013; Narouei Khandan 2014). Clark (2011) identified variable economic and environmental impacts and recognised moderate to high potential socio-cultural consequences for all New Zealanders. However, the sociocultural consequences for Māori have not been explored in any detail. Similarly, Loope (2010), in summarising the risk of additional strains of P. psidii to Hawai'i, provided only a short paragraph on the threat to Hawai'ian indigenous culture. There appears to be no comment in the literature on the the impact of $P$. psidii to Australian Aboriginal communities and culture.

The flora and fauna of the bush are taonga (or treasure) species and the Māori relationship with them is one of kaitiakitanga (guardianship); this relationship is multifaceted and intimate, developing over more than 40 generations (Waitangi Tribunal 2011). Taonga species may be part of a defined list (e.g. DOC 2006) or more generally any species of importance to Māori, and may include both indigenous and nonindigenous species (e.g. kūmara, taro, kiore, wild pig) (Roberts 2009). The WAI 262 claim Ko Aotearoa Tēnei (This is Aotearoa or This is New Zealand) (Waitangi Tribunal 2011) informs us that "iwi have relationships with species which are emblematic and have a spiritual element to them and their connection to the wider ecosystem particularly with regard to native plants such as harakeke, koromiko, pōhutukawa, kōwhai, puawānanga, poroporo, kawakawa, mānuka and kūmara" (Katene 2011). Taonga include tangible things such as land, waters, plants, wildlife and cultural works, and intangible things such as language, identity and culture, including Mātauranga Māori (the Māori way of viewing the world) (Waitangi Tribunal 2011).

This paper provides information on the invasive biology of myrtle rust, a list the indigenous Myrtaceae found in New Zealand, and a summary of the modest amount of information known about $P$. psidii infection for these New Zealand species. The Māori uses, values and relationships of these species is explored and the possible impact of myrtle rust considered in this context if myrtle rust was to become established in New Zealand.

\section{MYRTLE RUST BIOLOGY AND IMPACT}

Myrtle rust (also known as guava rust, eucalyptus rust and ōhi'a rust) was first described from Psidium guajava (native guava) in Brazil (Winter 1884). The native range of myrtle rust was reported to be South and Central America and the Caribbean (Coutinho et al. 1998; Silva et al. 2013). In the 1970s, the pathogen caused severe damage in nurseries and eucalyptus plantations in Brazil (Coutinho et al. 1998). The literature reports numerous strains of $P$. psidii that have differential ability to infect different suites of host plants (Loope 2010). It is considered that there is only a single strain in Australia (Carnegie \& Cooper 2011). Like many rusts, myrtle rust has a complex life cycle (Glen et al. 2007), which needs to be understood for the development of effective contingency plans for readiness and response to potential incursions. The spores are easily dispersed and can remain viable in the environment for several weeks (Clark 2011).

Since the 2000s, P. psidii has steadily spread around the world and is now found in Australia (including Tasmania) (Carnegie et al. 2010), South Africa (Roux et al. 2013) and New Caledonia (CABI 2014). Currently, 346 species from 57 genera (73 worldwide) from the Myrtaceae are reported to be susceptible to myrtle rust in Australia and elsewhere (Giblin \& Carnegie 2014a,b).

Myrtle rust attacks young, actively growing leaves, shoots, fruits and flowers (Glen et al. 2007). Leaves and stems become deformed and in severe infections growing tips (Coutinho et al. 1998) and the whole plants (Uchida \& Loope 2009) can die. Previous rust infection can also result in defoliation and prolific branching and galling. Floral buds and fruits can also be affected, with subsequent impacts on nectar production and reproduction (Glen et al. 2007).

Puccinia psidii effects can be variable. It is rarely severe on native Central and South 
American flora, although can cause occasional epidemics on native guava plantations (Ribeiro \& Pommer 2004). Similarly, over a period of 30 years, this rust has done little damage to any of the scattered native Myrtaceae in Florida (Loope 2010). Florida's native Myrtaceae are among the roughly 1,100 neotropical species that are largely resistant to $P$. psidii but the 3,000 species of nonneotropical Myrtaceae of the Pacific, Australia, Asia and Africa are expected to prove much more vulnerable to $P$. psidii (Loope 2010). In Hawai'i, crown dieback and complete tree death was recorded at a landscape scale from stands of the non-native Syzigyium jambos (Uchida \& Loope 2009) and the damage to Eugenia koolauensis, a federally listed endangered species, is of major concern (Loope 2010). The impact of P. psidii on individual trees and shrubs in Australia has ranged from minor leaf spots, foliage, stem and branch dieback to reduced fecundity. Tree death, as a result of repeated infection, has been recorded for Rhodomyrtus psidioides. The full impact of this disease in Australia may not be realized for some years (Pegg et al. 2014). Puccinia psidii is currently not causing serious disease in eucalypt plantations in Australia (Carnegie 2015).

\section{NEW ZEALAND INDIGENOUS MYRTACEAE AND MYRTLE RUST}

In New Zealand the Myrtaceae is represented by some of our best-known native plants such as the iconic pōhutukawa (Metrosideros excelsa), rata (Metrosideros diffusa), kanuka (Kunzea spp.) and manuka (Leptospermum scoparium), as well as lesser-known species such as swamp maire (Syzygium maire) and ramarama (Lophomyrtus bullata) (Clark 2011), and species that are considered nationally critical, such as Metrosideros bartlettii, with only 29 individuals left in the wild (De Lange et al. 2004). The Flora of New Zealand database (Landcare Research 2015) lists 29 indigenous taxa from the Myrtaceae, 27 of which are endemic. De Lange (2014a) has recently increased the number of New Zealand indigenous Kunzea species to ten, further increasing the number of indigenous Myrtaceae. New Zealand also has a large number of exotic Myrtaceae species, many of which have commercial value, such as Eucalyptus species and feijoa (Acca sellowiana (O. Berg.)), and some myrtaceous species that grow in New Zealand are weeds (e.g. Syzygium smithii) (Clark 2011).

All myrtaceous species (introduced and indigenous) found in New Zealand are considered to be potential hosts for myrtle rust. Some, mostly introduced plant species, found in New Zealand are known hosts for myrtle rust overseas (Giblin \& Carnegie 2014a,b). Nine New Zealand indigenous species from four genera are known to be susceptible to myrtle rust from observations made on these plant species in the laboratory and in the field in Australia and Hawai'i (Table 1). In addition, numerous non-New Zealand species from the genera found in New Zealand (including Syzgium) have been recorded as myrtle rust hosts (Giblin \& Carnegie 2014a,b), but little is known about the potential degree of susceptibility of New Zealand myrtaceous species. All species (including some New Zealand indigenous species) listed as myrtle rust hosts in New South Wales are considered to be susceptible to severe infestation under conducive conditions (Anonymous 2012). Loope (2010) reported that a few inviduals of pōhutukawa in the Lyon Arboretum in Hawai'i were seriously damaged by myrtle rust. Even though all New Zealand plant species from the Myrtaceae are at risk from myrtle rust it is not known which myrtaceous species will be susceptible, or how susceptible they will be.

\section{MĀORI USE, TAONGA AND MYRTACEAE}

A number of New Zealand's Myrtaceae species were extensively used by Māori, including for medicine, construction and food, or have significant cultural value as summarized in Appendix 1 (collated by Scheele 2014). Information on the current use of these plants by Māori is likely to be iwi- and hapu-specific and difficult to obtain and catalogue (Scheele 2014).

A number of plant species from the Myrtaceae have been explicitly identified as taonga species (e.g. DOC 2006; Waitangi Tribunal 2011), in particular, the importance of pōhutukawa and mānuka to Māori (the WAI 262 claim; Waitangi Tribunal 2011). 
Table 1 Records of myrtle rust (caused by Puccinia psidii) from New Zealand indigenous plant species. Sources: All Australian records are from Giblin \& Carnegie (2014a), except for Lophomyrtus obcordata, which is from P. Symes (Royal Botanic Gardens, Melbourne, Australia, personal communication). All Hawai'ian records are from Loope (2010). There are no additional records of New Zealand indigenous plant species being infected by myrtle rust from the rest of the world (Giblin \& Carnegie 2014b).

\begin{tabular}{|c|c|c|}
\hline Host taxa & $\begin{array}{c}\text { Natural infection }=\text { wild, open cultivation } \\
\text { or greenlife industry }\end{array}$ & $\begin{array}{c}\text { Deliberate } \\
\text { inoculation test }\end{array}$ \\
\hline Kunzea ericoides $^{1}$ & & Aust \\
\hline Leptospermum scoparium & & Aust \\
\hline Lophomyrtus bullata & Aust: NSW ${ }^{2}$ & \\
\hline Lophomyrtus $\times$ ralphii & Aust: NSW\& Vic & \\
\hline Lophomyrtus obcordata & Aust: Vic & \\
\hline Metrosideros carminea & Aust: Vic & \\
\hline Metrosiderus excelsa & Aust: NSW \& Vic, Hawai'i & Aust \\
\hline Metrosiderus kermadecensis & Aust: Qld \& NSW, Hawai'i & \\
\hline Metrosideros thomasii & Aust: Qld & \\
\hline
\end{tabular}

Pōhutukawa (New Zealand Christmas tree) is one of New Zealand's most widely recognised trees, with brilliant red flowers and is a treasured ornamental plant. Pōhutukawa's deep-red wood is exceptionally strong (Metrosideros means 'iron hearted') with various uses (Appendix 1). The flower nectar and bark preparations were used for various medicinal purposes (Appendix 1). Pale cream-coloured pōhutukawa honey is produced commercially. Pōhutukawa also has significant cultural and spiritual value to Māori. A specific named tree, Te Reinga (older than 800 years), found on a cliff face at Te Rerenga Wairua (Cape Rēinga), has a central place in Māori tradition as it is said to guard the entrance to the sacred cave through which spirits pass on their way to the next world (Hawaiki). Another significant pōhutukawa is Karewa, in Kawhia Harbour, said to be the tree to which the Tainui waka was tied after completing its voyage across the Pacific from Hawaiki (Waitangi Tribunal 2011). At least 350 years old, Te Waha o Rerekohu, at Te Araroa, near the East Cape, is probably New Zealand's largest pōhutukawa (19.8 $\mathrm{m}$ high $\times 38.5 \mathrm{~m}$ wide). The poihutukawa is the subject of numerous stories. Perhaps the best-known tells of the young warrior,
Tawhaki, and his attempt to find help in heaven to avenge his father's death. The pōhutukawa's flowers are said to represent Tawhaki's blood, shed after he fell to earth. There are numerous stories and pepeha (sayings) that tell of the relationship between the blooms of the pōhutukawa and the plume of red feathers worn as a headdress by the Hawaiikian voyagers (Waitangi Tribunal 2011).

Mānuka (tea tree) is one of New Zealand's most common native trees and Māori use of this tree has been extensive (Appendix 1). Mānuka wood has been used for firewood, a range of tools, building materials and weapons. Leaf and bark preparations were used for a wide variety of medicinal purposes (Waitangi Tribunal 2011). Today, mānuka oil is recognised for its antibacterial, antifungal and antihistamine properties, and is used to treat a number of conditions. Mānuka honey is used as a general tonic, in wound-care products and in cosmetic skincare products. In 2014, New Zealand honey exports had a total value of $\$ \mathrm{NZ186.6 \textrm {M }}$ (Fresh Facts 2014), mostly due to the premium price achieved by mannuka honey, which is approximately three times higher than that of other table honey (Coriolis 2012). 


\section{POTENTIAL IMPACTS OF MYRTLE RUST ON TAONGA SPECIES}

Australia seems the most likely source for a New Zealand myrtle rust incursion as it it one of our major trading partners and the source of many of our tourists. Rust spores are easily carried on clothing and this pathway is a very likely source of accidental introduction to new areas. Additionally, a range of fungal rusts are thought to have arrived in New Zealand from Australia through prevailing westerly wind currents (Kim \& Beresford 2008; Viljanen-Rollinson \& Cromey 2002). Therefore all New Zealand myrtaceous genera and species are expected to be at risk because the Australian biotype has a particularly wide host range (see above). Currently, MPI has suspended imports of cut flowers and foliage from Australian states where $P$. psidii is present (Queensland, New South Wales, Victoria and Tasmania; http://www.mpi.govt.nz/) to prevent their entry into New Zealand. Once established myrtle rust is likely to spread quickly throughout New Zealand at least in the North Island. Climate matching models suggest that myrtle rust will have the greatest impact in the North Island (Kriticos et al. 2013, Narouei Khandan 2014) and species found predominantly in the South Island, such as southern rata (Metrosideros umbellata), may be at reduced risk. Which particular New Zealand genera and species will be most susceptible to myrtle rust is unknown, but greater information gathered from New Zealand native species grown in Australia (and possibly Hawai'i), especially from similar climates, may provide some clues, especially on their relative susceptibility.

Potential impacts of myrtle rust are likely to be variable. It mostly affects young plants and young tissues including flowers, and although tree death has been reported it is not the norm (Pegg et al. 2014). Thus individual rakau rangatira (chiefly trees) such Te Reinga, Te Waha o Rerekohu and Karewa are unlikely to be killed. However, their outward appearance, especially during periods of bud growth and flowering, might be affected. Similarly, uses of pōhutukawa and mānuka timber for construction and tools may not be too seriously affected; impacts on long-lived trees species, such as pōhutukawa, will be less obvious in the short term but may be significant in the long term. There are also likely to be intangible impacts because of the close relationship between Māori in their role as kaitiaki of taonga species, and for smaller Maori groups who have close connections to individual rakau rangatira, which have a central role in various pepeha and stories.

Future regeneration may be at risk as a result of increased seed and seedling mortality during severe infestations, as has been reported for $R$. psidioides in Australia (Pegg et al. 2014). This may be especially apparent for species such as kānuka and mānuka, which are important in the development of early successional plant communities.

Loss of flowers and new growth has a number of potentially significant implications. Honey production for both pōhutukawa and mānuka may be significantly affected in terms of both productivity and quality. Similarly, the quality of medicinal (traditional/rongoa and modern) products from key species may also be compromised. Impacts in this area may very much depend on which elite honey and medicinal plant biotypes are affected by myrtle rust.

\section{WIDER DISCOURSE WITH MĀORI}

Two summer students have been hosted by Better Border Biosecurity/Plant \& Food Research to explore the potential impact of myrtle rust on plant species of interest to Māori. Alipia (2014) focussed more on the invasive biology of myrtle rust and its potential impact on New Zealand plant species whereas Ropata (2015) focussed more on engagement with Māori communities and their views of myrtle rust and its potential impact on plant species of interest to them. In particular, Ropata (2015) developed a focus group facilitated discussion process that was trialled with two Māori students (summer and post-graduate), one Māori scientist and one Māori support staff (total $n=4$ ) at Plant \& Food Research in February 2015 to understand their knowledge of myrtle rust, which taonga plant species were important to them, and why and how they would like to be involved in an incursion response (Ropata 2015). While the makeup of this group was small and 
probably not representative of the wider Māori community it did provide some insights into some of the potential concerns that Māori have over myrtle rust. Other commentators have indicated a strong interest by Māori in biosecurity issues, e.g. Flavell (2010).

One issue that clearly emerged from this preliminary engagement was that Māori communities and iwi authorities would very much like, and prioritise, is early involvement in the preparedness and response to myrtle rust (Ropata 2015). A tāngata whenua (local people) rōpu (group) was established in response to the discovery of kauri dieback and a similar partnership approach would provide strategic insight and knowledge (mātauranga Māori) for managing any myrtle rust incursions. Given the threat and likelihood of myrtle rust incursion, an early engagement approach to establish ongoing interactions between practitioners of kaitiakitanga (environmental stewards, guardians) and tāngata whenua groups, land managers and research scientists should be initiated. This approach would enable the implementation of mahi (work) to survey, catalogue and monitor sentinel plants for their growth and health status. Tāngata whenua are very familiar with their land and any taonga species plants that are present in their rohe (area), and can provide the local knowledge and expertise for any surveys and cataloguing of sentinel plants for their growth and health status, or lack thereof, over time and space. This knowledge and sentinel plant data could feed into a larger repository of information that could serve as a national network of plant health status. Collectively, this nationwide sentinel network may also form an ara (pathway) for two-way knowledge exchange, resulting in increased preparedness for a myrtle rust incursion and an early and successful response.

\section{SUMMARY}

Myrtle rust is a significant disease of plants in the Myrtaceae and has been spreading rapidly around the world in recent years and is now in Australia. It seems likely to reach New Zealand and it may affect all Myrtaceae to some extent, but especially in the North Island. While there has been significant discourse about the economic and environmental impacts of myrtle rust for New Zealand, there has been little on the likely cultural impacts (at least in published literature) for Māori and their connections to taonga species. This paper has attempted to identify some potential cultural impacts, but a wider kōrero (discourse) with tāngata whenua would be needed to provide a comprehensive understanding. Such a kōrero will be important in terms of readiness and response for this disease if it enters New Zealand. In preliminary engagement, Māori have shown interest and expectation to be involved in such a response, including conducting surveillance of sentinel plants within New Zealand. Fortunately, a number of indigenous New Zealand plants are grown in Australia (and elsewhere) where myrtle rust is now endemic. Quantitative information on disease incidence from these sources would also be a useful resource for understanding the likely impact in New Zealand before it arrives here.

\section{ACKNOWLEDGEMENTS}

We thank Peter Symes of Royal Botanic Gardens, Melbourne, Australia, for information on New Zealand native Myrtaceae in Australia. This work was funded through Plant \& Food Research internal funding aligned to the research collaboration Better Border Biosecurity.

\section{REFERENCES}

Anonymous 2012. Myrtle rust host list. http:// www.dpi.nsw.gov.au/biosecurity/plant/ myrtle-rust/hosts (accessed 30 April 2015).

Anonymous 2015. Information on Myrtaceae species traditional uses and distribution http://www.terrain.net.nz/friends-ofte-henui-group/table-1/ramaramalophomyrtus-bullata.html (accessed 11 May 2015).

Alipia TT 2014. Impact of Puccinia psidii on Māori taonga plant species. Plant \& Food Research Internal Report, Plant \& Food Research, Christchurch, New Zealand.

Bylsma RJ, Clarkson BD, Efford JT 2014. Biological flora of New Zealand 14: Metrosideros excelsa, pōhutukawa, New Zealand Christmas tree. New Zealand Journal of Botany 52: 365-385. 
CABI 2014. Puccinia psidii (guava rust): Crop Protection Compendium. http://www.cabi. org $/ \mathrm{cpc} /$ ? compid $=1 \& \mathrm{~d}$ sid $=45846 \&$ load module $=$ datasheet $\&$ page $=868 \&$ site $=161$ (accessed 19 April 2015).

Carnegie AJ 2015. First report of Puccinia psidii (myrtle rust) in Eucalyptus plantations in Australia. Plant Disease 99: 161.

Carnegie AJ, Cooper K 2011. Emergency response to the incursion of an exotic myrtaceous rust in Australia. Australasian Plant Pathology 40: 346-359.

Carnegie AJ, Lidbetter JR, Walker J, Horwood MA, Tesoriero L, Glen M, Priest MJ 2010. Uredo rangelii, a taxon in the guava rust complex, newly recorded on Myrtaceae in Australia. Australasian Plant Pathology 39: 463-466.

Clark S 2011. Risk analysis of the Puccinia psidii/ Guava Rust fungal complex (including Uredo rangelii/Myrtle Rust) on nursery stock. Ministry of Agriculture and Forestry, Wellington, New Zealand.

Coriolis 2012. Investment opportunities in the honey industry. http://www.med.govt.nz/ sectors-industries/food-beverage/pdf-docslibrary/information-project/coriolis-reportinvestment-opportunities-honey-industry. pdf (accessed 4 April 2015).

Coutinho TA, Wingfield MJ, Alfenas AC, Crous PW 1998. Eucalyptus rust: A disease with the potential for serious international implications. Plant Disease 82: 819-825.

Dawson JW 1985. Metrosideros bartlettii (Myrtaceae) a new species from North Cape, New Zealand. New Zealand Journal of Botany 23: 607-610.

De Lange PJ 2014a. A revision of the New Zealand Kunzea ericoides (Myrtaceae) complex. PhytoKeys 40: 1-185.

De Lange P 2014b. Metrosideros bartlettii. http://www.iucnredlist.org/details/34295/0 (accessed May 2015).

De Lange P, Norton D, Heenan P, Courtney S, Molloy B, Ogle C, Rance B, Johnson P, Hitchmough R 2004. Threatened and uncommon plants of New Zealand. New Zealand Journal of Botany 42: 45-76.
DOC 2006. Department of Conservation. Ngäi Tahu taonga plant species. http://www.doc. govt.nz/documents/about-doc/concessionsand-permits/conservation-revealed/ngaitahu-taonga-plants-lowres.pdf (accessed 15 May 2015).

Flavell TU2010.9December2010,669;NewZealand Parliamentary Debate Page:16210. http:// www.parliament.nz/minz/pb/debates/debates/ speeches/49HansS_20101210_00002016/ flavell-te-ururoa-biosecurity-law-reform-bill\%e2\%80\%94-first) (accessed 1 May 2015).

Fresh Facts 2014. New Zealand Horticulture. http://www.freshfacts.co.nz/file/fresh-facts 2014.pdf (accessed 10 May 2015).

Glen M, Alfenas AC, Zauza EAV, Wingfield MJ, Mohammed C 2007. Puccinia psidii: a threat to the Australian environment and economy a review. Australasian Plant Pathology 36: 1-16.

Giblin F, Carnegie AJ 2014a. Puccinia psidii (Myrtle Rust) - Australian host list. Version current at 24 Sept. 2014. http://www.anpc. asn.au/resources/Myrtle_Rust.html (accessed 9 June 2015).

Giblin F, Carnegie AJ 2014b. Puccinia psidii (Myrtle Rust) - Global host list. Version current at 24 Sept. 2014. https://www.anbg. gov.au/anpc/images/Puccinia\%20psidii $\% 20$ Global\%20Host\%20List\%202014\%20-\%20 MERGED\%20COMPLETE\%2024Sept2014. pdf (accessed 9 June 2015).

Katene R 2011. Rahui Katene Speech: Biosecurity Law Reform Bill. http://pacific. scoop.co.nz/2011/08/rahui-katene-speechbiosecurity-law-reform-bill/ (accessed 2 April 2015).

Kim KS, Beresford RM 2008. Use of a spectrum model and satellite cloud data in the simulation of wheat stripe rust (Puccinia striiformis) dispersal across the Tasman Sea in 1980. Agricultural and Forest Meteorology 148: 1374-1382.

Knightbridge PI, Ogden J 1998. Establishment patterns and host tree preferences of the emergent hemi-epiphytic tree Metrosideros robusta in northern New Zealand. New Zealand Journal of Botany 36: 203-212. 
Kriticos DJ, Morin L, Leriche A, Anderson RC, Caley P 2013. Combining a climatic niche model of an invasive fungus with its host species distributions to identify risks to natural assets: Puccinia psidii Sensu Lato in Australia. PLoS One 8(5): e64479.

Landcare Research 2015. Flora of New Zealand. www.nzflora.info/factsheet/Taxon/ Myrtaceae.html (accessed 5 June 2015).

Loope L 2010. A summary of information on the rust Puccinia psidii Winter (guava rust) with emphasis on means to prevent introduction of additional strains to Hawai'i: U.S. Geological Survey Open-File Report 2010-1082. http:// pubs.usgs.gov/of/2010/1082/ (assessed 10 May 2015).

Narouei Khandan HA 2014. Ensemble models to assess the risk of exotic plant pathogens in a changing climate. $\mathrm{PhD}$ thesis, Lincoln University, Lincoln, New Zealand. 280 p.

NZPCN (New Zealand Plant Conservation Network database) http://www.nzpcn.org.nz/ default.aspx (accessed 12 May 2015).

Pegg GS, Giblin FR, McTaggart AR, Guymer GP, Taylor H, Ireland KB, Shivas RG, Perry S 2014. Puccinia psidii in Queensland, Australia: disease symptoms, distribution and impact. Plant Pathology 63: 1005-1021.

Ribeiro IJA, Pommer CV 2004. Breeding guava (Psidium guajava) for resistance to rust caused by Puccinia psidii. Acta Horticulturae 632: 75-78.

Roberts M 2009. Looking backwards into the future. Biosecurity 90: 4-6. MAF Biosecuity, Wellington, New Zealand.

Ropata H 2015. The impact of myrtle rust on Māori taonga plant species and their use. Plant \& Food Research Internal Report, SPTS No. 11156. Plant \& Food Research, Christchurch, New Zealand.
Roux J, Greyling I, Coutinho TA, Verleur M, Wingfield MJ 2013. The Myrtle rust pathogen, Puccinia psidii, discovered in Africa. IMA Fungus 4: 155-159.

Scheele 2014. Ngā Tipu Whakaoranga Māori-plant-use-database. http://www. landcareresearch.co.nz/resources/data/ngatipu-whakaoranga-maori-plant-use-database (accessed 30 April 2015).

Silva PHM, Miranda AC, Moraes MLT, Furtado EL, Stape JL, Alvares CA, Sentelhas PC, Mori ES, Sebbenn AM 2013. Selecting for rust (Puccinia psidii) resistance in Eucalyptus grandis in São Paulo State, Brazil. Forest Ecology and Management 303: 91-97.

Stephens JMC, Molan PC, Clarkson BD 2005. A review of Leptospermum scoparium (Myrtaceae) in New Zealand. New Zealand Journal of Botany 43: 431-449.

Uchida JY, Loope LL 2009. A recurrent epiphytotic of guava rust on rose apple, Syzygium jambos, in Hawai'i. Plant Disease 93: 429-429.

Viljanen-Rollinson SLH, Cromey MG 2002. Pathways of entry and spread of rust pathogens: Implications for New Zealand's biosecurity. New Zealand Plant Protection 55: 42-48.

Waitangi Tribunal 2011. Ko Aotearoa tēnei. A Report into Claims Concerning New Zealand Law and Policy Affecting Māori Culture and Identity. Te Taumata Tuarua. Volume 1. WAI 262. Waitangi Tribunal Report 2011, Legislation Direct, Wellington, New Zealand.

Wardle P 1971. Biological flora of New Zealand 6. Metrosideros umbellata Cav. [Syn. M. lucida (Forst.f.) A. Rich.] (Myrtaceae) Southern rata. New Zealand Journal of Botany 9: 645-671.

Winter G 1884. Repertorium Rabenhorstii fungi europaei et extraeuropaei (in German). Cent XXXI et XXXII Hedwigia 23: 164-175. 


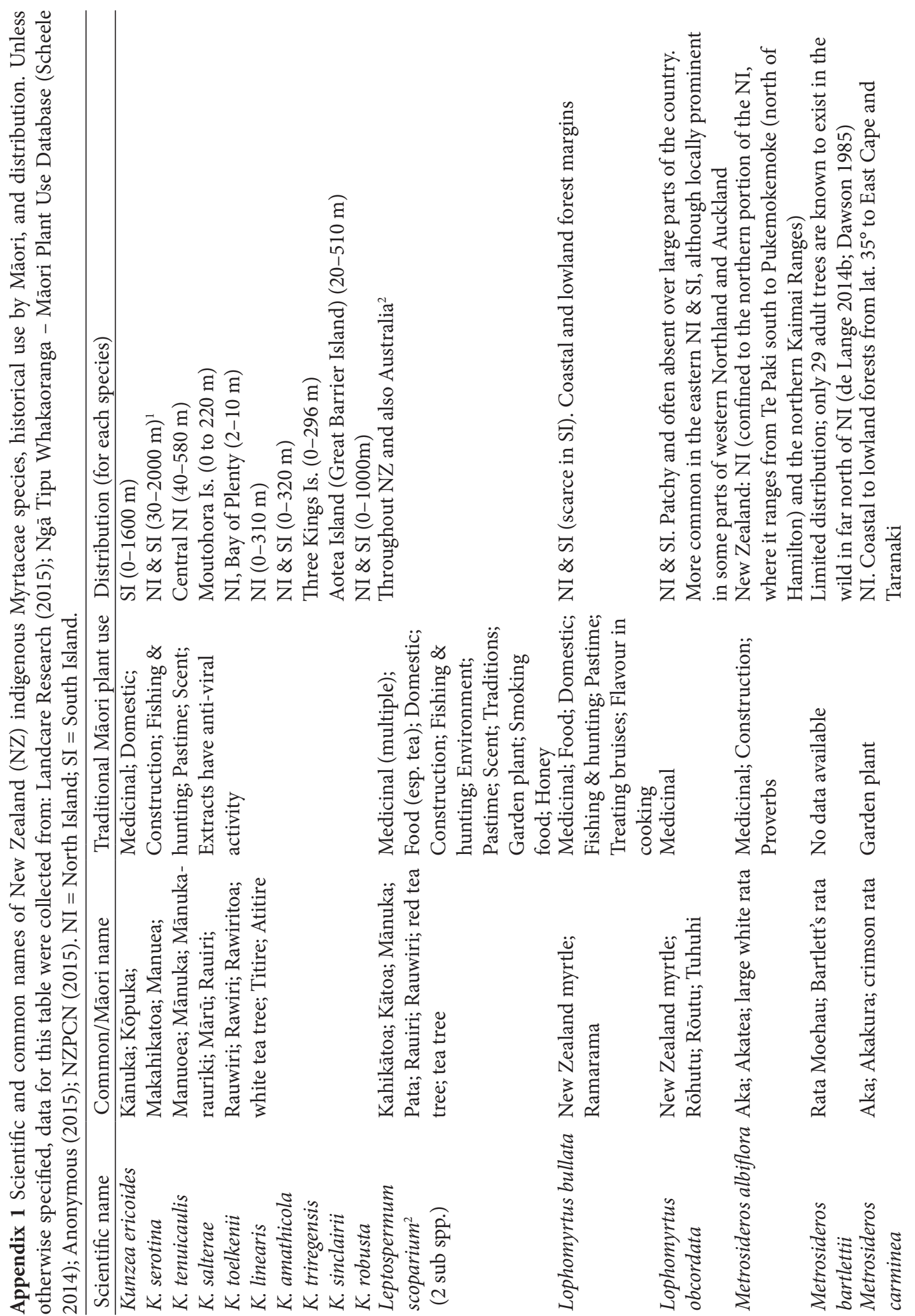




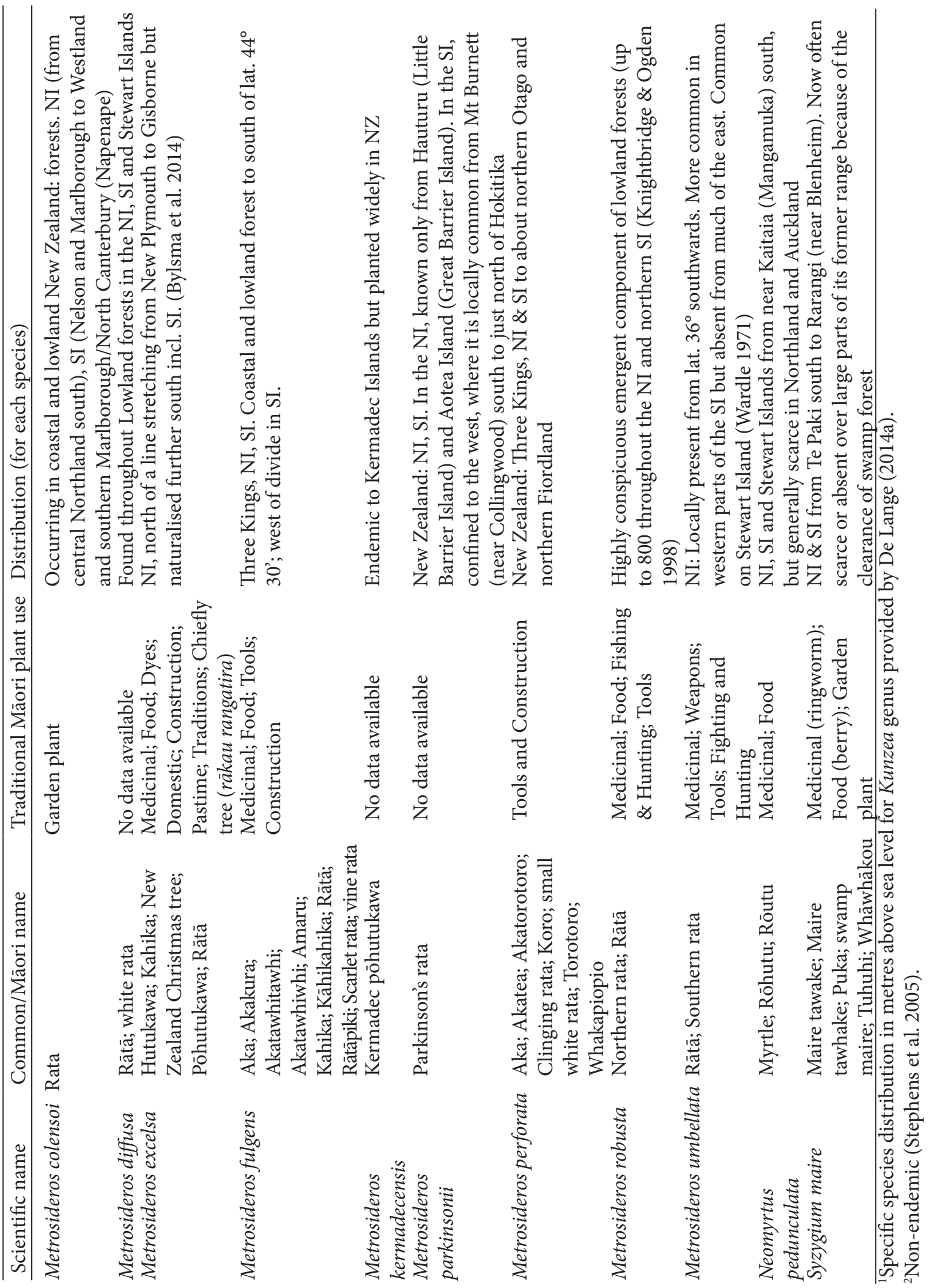

